\title{
OCZYSZCZENIE PO ŚMIERCI - HERMENEUTYKA DEFINICJI DOGMATYCZNEJ O CZYŚĆCU
}

Niewiele jest prawd katolickiej wiary, które aż tak bardzo absorbują ludzką ciekawość i wyobraźnię jak związany z przekroczeniem progu śmierci czyściec. Nie jednak dzięki popularnym czy obiegowym wyobrażeniom - niejednokrotnie ubarwionym plastycznymi formami wyrazu i materialno-przestrzennymi kategoriami - możliwe jest dotarcie do istotnej treści katolickiej nauki o czyśćcu. Istotnym postulatem pod adresem czyśćca jest dziś taka jego hermeneutyka, która pozwala zrozumieć człowiekowi współczesnemu jego potrzebę i naturę. Podczas, gdy zwłaszcza przed Soborem Watykańskim II refleksja prezentująca prawdy wiary koncentrowała się bezpośrednio na Piśmie Świętym i Magisterium Kościoła, tak po Vaticanum II teologia koncentrując się na poszczególnych wypowiedziach doktrynalnych i formułach wiary, stara się ukazać je w ich nierozerwalnym związku z teraźniejszością ${ }^{1}$. W ten sposób na znaczeniu zyskała tak interpretacja, jak i aktualizacja słowa Bożego i poszczególnych wypowiedzi doktrynalnych, w tym także, w odniesieniu do

* KS. SYLWESTER JAŚKIEWICZ - kapłan diecezji radomskiej. W latach 1995-200o studiował w Rzymie na Papieskim Uniwersytecie Gregoriańskim, gdzie uzyskał stopień doktora teologii na podstawie pracy o Bożym miłosierdziu w Komentarzu do Psalmów św. Augustyna. Po powrocie do Polski był wykładowcą teologii dogmatycznej w Instytucie Teologicznym w Radomiu Uniwersytetu Kardynała Stefana Wyszyńskiego w Warszawie. W Radomskiej Kurii Biskupiej pełnił obowiązki wizytatora, a następnie dyrektora Wydziału Katechetycznego. Od 2012 roku jest proboszczem parafii w Wieniawie. W 2014 roku uzyskał stopień doktora habilitowanego nauk teologicznych na Wydziale Teologicznym UKSW w Warszawie. Jako dogmatyk, w swoich zainteresowaniach naukowych koncentruje się na trynitologii, charytologii, eklezjologii oraz eschatologii. Szczególnie bliska jest mu osoba i spuścizna wielkiego myśliciela starożytności chrześcijańskiej - św. Augustyna. Jest autorem kilku książek oraz licznych artykułów z dziedzin: teologii, patrologii, katechetyki i duszpasterstwa.

1 Jak podkreśla J. O’Donnell, „zadaniem hermeneutyki jest zrozumienie przeszłości, ale nie w jej niepowtarzalnej faktyczności. Interpretator pragnie zrozumieć przeszłość raczej w jej otwartości na przyszłość, albo, innymi słowy, w świetle teraźniejszości i w świetle własnych pytań”. Wprowadzenie do teologii dogmatycznej, tłum. J. D. Szczurek, Kraków 1997, s. 74. 
czyśćca jako jednego z klasycznych tematów nauki o rzeczach ostatecznych. Hermeneutyka zajmując godne uwagi miejsce w aktualizującej interpretacji dogmatów ma w sobie także niezaprzeczalne ograniczenia, na co zwróciła uwagę Międzynarodowa Komisja Teologiczna w jednym ze swoich dokumentów, przestrzegając zwłaszcza przed zagubieniem prawdy objawionej ${ }^{2}$. Gdy jednak zabraknie dziś poprawnej hermeneutyki wiary w odniesieniu do tekstów natchnionych i dogmatów Kościoła „jej miejsce nieuchronnie zajmuje inna hermeneutyka, hermeneutyka zlaicyzowana, pozytywistyczna, której podstawą jest przekonanie, że pierwiastek Boży nie występuje w ludzkich dziejach. Zgodnie z tą hermeneutyką, kiedy zdaje się, że element Boski istnieje, trzeba go wyjaśnić w inny sposób i sprowadzić wszystko do elementu ludzkiego"3. Ponieważ każdy tekst można zinterpretować różnorako stąd poprawna hermeneutyka doktrynalnych wypowiedzi Kościoła pozwala ustrzec je przed interpretacjami niewłaściwymi i niebezpiecznymi.

\section{Hermeneutyka w eschatologii}

Niezwykle ważna w lekturze Biblii ${ }^{4}$, a także w całej teologii ${ }^{5}$, hermeneutyka, czyli sztuka tłumaczenia, znalazła swoje uprzywilejowane miejsce w eschatologii ${ }^{6}$. O ile bowiem, w odniesieniu do całej teologii, hermeneutyka staje się niezbędnym narzędziem w poszukiwaniu prawdy i w jej ukazywaniu, tak w odniesieniu do eschatologii staje się ona tym bardziej użyteczna, gdyż pomaga zrozumieć liczne obrazy i figury, a także język opisowy, który im towarzyszy. Zastosowanie

2 „Teologia współczesna o ukierunkowaniu hermeneutycznym szuka możliwości rzucenia pomostu między tradycją dogmatyczną i myślą współczesną, stawiając kwestię sensu i znaczenia dogmatów dla człowieka dzisiejszego. W ten sposób jednak oddziela się poszczególne formuły dogmatyczne od ich powiązania z Paradosis i izoluje się je od wiary przeżywanej przez Kościół. Następuje więc 'urzeczowienie' dogmatu; ponadto, stawiając w centrum problem znaczenia praktycznego, egzystencjalnego lub społecznego dogmatu, traci się z oczu kwestię jego prawdy”. Interpretacja dogmatów, A, II, 2, w: Od wiary do teologii. Dokumenty Międzynarodowej Komisji Teologicznej 1969-1996, red. J. Królikowski, Kraków 2000, s. 277.

3 Benedykt XVI, Posynodalna adhortacja apostolska Verbum Domini, 35.

4 Znamienne w tym względzie są słowa papieża Jana Pawła II: „Nie należy też lekceważyć niebezpieczeństwa, na jakie narażeni są ci, którzy próbują odczytać prawdę Pisma Świętego przy pomocy jednej tylko metodologii, zapominając o potrzebie bardziej wyczerpującej egzegezy, która pozwoliłaby im odkryć wraz z całym Kościołem pełny sens tekstów. Kto zajmuje się badaniem Pism Świętych, powinien zawsze pamiętać, że różne metodologie hermeneutyczne również opierają się na określonych koncepcjach filozoficznych, należy je zatem wnikliwie oceniać przed zastosowaniem ich do analizy świętych tekstów”. Encyklika Fides et ratio, 55.

5 Por. Scuola di Teologia del Seminario di Bergamo (a cura di), Teologia dal Vaticano II. Analisi storiche e rilievi ermeneutici, Cinisello Balsamo 2012.

6 Por. E. Castellucci, Nella pienezza della gioia pasquale. La centralità dell'ermeneutica nell'escatologia cristiana, Bologna 1998. 
hermeneutyki $\mathrm{w}$ eschatologii wiąże się $\mathrm{w}$ praktyce nie tyle $\mathrm{z}$ ukazaniem wiarygodności jakichś elementów drugorzędnych wiary, co stoi u podstaw samej wiarygodności całego chrześcijaństwa, rozumianego zwłaszcza jako integralny system dogmatyczny i moralny. Począwszy zwłaszcza od pierwszych zachęt Hansa Ursa von Balthasara (1905-1988) i Karla Rahnera (1904-1984) do większego zastosowania hermeneutyki w eschatologii, teologia katolicka poczyniła znaczne postępy. Za najbardziej znaczące osiągnięcia uznać należy: organiczną i całościową wizję eschatologii, która zastąpiła rozczłonkowanie właściwe dla tradycyjnego traktatu De Novissimis; chrystocentryzm w interpretacji podstawowych wypowiedzi eschatologicznych; przezwyciężenie fizycyzmu, czyli ujmowania człowieka i jego przyszłości w kategoriach fizykalnych; zachowanie wymiaru tajemnicy towarzyszące przekonaniu o niemożliwości wyjaśnienia wszystkiego; usunięcie rozdźwięku pomiędzy rzeczywistością przyszłą a obecną; przezwyciężenie dualistycznej wizji pomiędzy eschatologią biblijną (zmartwychwstaniem), a grecką (nieśmiertelnością)7.

\section{Metoda i kryteria hermeneutyki eschatologicznej}

Centralne miejsce Pisma Świętego w teologii łączy się z kwestią właściwej interpretacji jego treści. Jednym z pierwszoplanowych zagadnień jest tu zachowanie równowagi pomiędzy dosłownym rozumieniem wypowiedzi biblijnych a równie bogatym w Biblii symbolizmem ${ }^{8}$. To, co eschatologiczne wyraża Pismo Święte za pomocą licznych obrazów, a ich dosłowne odczytanie oznaczałoby ogromne ich zubożenie. Obrazy eschatologiczne odnoszące się w pierwszej kolejności do eschatologii powszechnej albo uniwersalnej to: królestwo Boże, uczta, ciemności, płacz i zgrzytanie zębów, paruzja, dzień Pana, ogień i Gehenna, sąd, zmartwychwstanie umarłych, końcowa i ostateczna odnowa całego stworzenia, niebiańska Jerozolima, nowe niebiosa i nowa ziemia, millennium. Do eschatologii indywidualnej odnoszą się zaś: łono Abrahama, Hades, raj, zamieszkanie, strój, odejście, męczeństwo. Podczas, gdy niektóre obrazy są typu prorockiego, inne zaliczane są do apokaliptycznych. Nie zawsze dają się one łatwo zaszeregować i ze sobą pogodzić, nawet w obrębie tego samego rodzaju literackiego. W całościowym ujęciu „ich różność i niezgodność pozwoliły nam zrozumieć nie tylko, że one nie są traktowane tylko dosłownie, ale, że i my sami, kiedy głosimy przyszłość nie możemy wpływać na poszczególne obrazy, łatwo zrozumiałe i określone: wydaje się bardziej właściwa, jeśli już, pewna 'kompozycja' figur, aby się ze sobą zintegrowały

\footnotetext{
7 Por. E. Castellucci, Nella pienezza della gioia pasquale..., dz. cyt., s. 113.

8 Por. E. Castellucci, Nella pienezza della gioia pasquale..., dz. cyt., s. 115.
} 
i między sobą zrelatywizowały (np. przepowiadanie raju jako nieba razem z królestwem, miastem, domem Ojca, ucztą, ...), i przede wszystkim użycie analogii właśnie bardziej 'antropologicznych', o charakterze doświadczalnym, psychologicznym, relacyjnym (jako dojrzewanie, wypełnienie, komunia, pokój, lub samotność, niemożność komunikowania się, wewnętrzne rozdarcie itp.)"9. Zestawienie wielu odrębnych obrazów tworzy w swej całości jakby mozaikę, w której każdy z poszczególnych elementów w swej jedyności i niepowtarzalności przyczynia się do zrozumienia całości eschatologii chrześcijańskiej. Współczesna teologia katolicka czerpie niektóre wskazania z protestanckiej hermeneutyki Rudolfa Bultmanna, jak np. umiarkowanej demitologizacji, unikając przy tym: radykalizmu, $\mathrm{w}$ tym także w odniesieniu do symbolizmu; zastępowania chrystocentryzmu bardziej ogólnym „teocentryzmem”; negowania doniosłości historii na rzecz teraźniejszości egzystencjalnej ${ }^{10}$.

Podstawowym kryterium w interpretacji obrazów eschatologicznych jest kryterium chrystologiczne. Osoba i dzieło Jezusa Chrystusa, Jego męka, śmierć i zmartwychwstanie nie tylko rzuciły światło na to, co eschatologiczne, ale stanowią jego prawdziwe centrum. To, co ostateczne, oznacza nie miejsce i warunki przyszłego istnienia, ale relację do osoby Jezusa Chrystusa i pragnienie Jego bliskości ${ }^{11}$. Z kryterium chrystologicznym pozostaje w bliskim związku kryterium antropologiczne ${ }^{12}$.

\section{3. Źródła katolickiej nauki o czyśćcu}

Już we wstępie dyscyplinarnego Dekretu o czyśćcu Sobór Trydencki przypomina o niezbędnym oparciu podstawowych twierdzeń o czyśćcu o Pismo Święte i starożytną naukę Ojców. Sobór Trydencki „z jednej strony zakłada istnienie biblijnego fundamentu dla nauki Kościoła, a z drugiej - określa zasięg jego uzasadniającego działania. Biblia przekazuje jedynie to, czego Kościół dogmatycznie naucza, to znaczy, że istnieje czyściec i że dusze w nim przebywające mogą być wspomagane modlitwami wiernych żyjących na tym świecie. Ta ostatnia uwaga jest o tyle ważna, iż wyklucza wszelkie próby szukania w Biblii rozwiniętej idei czyśćca, która była owocem długiego procesu rozwoju ubogacanego niekiedy dowolnymi wyobrażeniami, wychodzącymi poza granice treści gwarantowanych

\footnotetext{
9 A. Rudoni, Introduzione all'escatologia, Torino 1988, s. 76.

${ }^{10}$ Por. E. Castellucci, Nella pienezza della gioia pasquale..., dz. cyt., s. 119-123.

${ }^{11}$ Por. E. Castellucci, Nella pienezza della gioia pasquale...,dz. cyt., s. 123.

12 Por. E. Castellucci, Nella pienezza della gioia pasquale...,dz. cyt., s. 119.124-125.
} 
przez objawienie"13. Źródła biblijne to zasadniczo dwa teksty: 2 Mch 12, 40-44 ${ }^{14}$ oraz 1 Kor $3,10-15^{15}$, które przygotowują naukę o czyśćcu poprzez ukazanie skuteczności modlitwy za zmarłych i ostatecznego oczyszczenia, ale nie można powiedzieć, że stwierdzają bezpośrednio istnienie czyśćca ${ }^{16}$. Mniej lub bardziej nawiązuje się też do innych tekstów ze Starego i Nowego Testamentu ${ }^{17}$.

Najstarsze świadectwa prawdy o czyśćcu zawierają się „w modlitwach za zmarłych (już od II w.), w modlitwach eucharystycznych (od III w.), w 'Konstytucjach Apostolskich’ (IV w.), w 'Euchologionie’ Serapiona z Tmuis” (IV w.) i w innych. Mieściła się szczególnie w teorii i praktyce pokuty kościelnej, która - jak sądzono - mogła być ‘kończona’ nawet po śmierci, gdyż do Boga mogą mieć przystęp jedynie czyści i święci”"18. Z początkami historii nauki o czyśćcu łączą się tacy myśliciele jak Tertulian na Zachodzie († po 220) oraz Klemens Aleksandryjski na Wschodzie ( $†$ przed 215$)^{19}$.

13 T. D. Łukaszuk, Ostateczny los człowieka i świata w świetle wiary katolickiej, Kraków 2006, s. 123-124.

14 „Pod chitonem jednak u każdego ze zmarłych znaleźli przedmioty poświęcone bóstwom, zabrane z Jamnii, chociaż Prawo tego Żydom zakazuje. Dla wszystkich więc stało się jasne, że to oni i z tej właśnie przyczyny zginęli. Wszyscy zaś wychwalali Pana, sprawiedliwego Sędziego, który rzeczy ukryte czyni jawnymi, a potem oddali się modlitwie i błagali, aby popełniony grzech został całkowicie wymazany. Mężny Juda upomniał lud, aby strzegli samych siebie i byli bez grzechu mając przed oczyma to, co się stało na skutek grzechu tych, którzy zginęli. Uczyniwszy zaś składkę pomiędzy ludźmi, posłał do Jerozolimy około dwu tysięcy srebrnych drachm aby złożono ofiarę za grzech. Bardzo pięknie i szlachetnie uczynił, myślał bowiem o zmartwychwstaniu. Gdyby bowiem nie był przekonany, że ci zabici zmartwychwstaną, to modlitwa za zmarłych byłaby czymś zbędnym i niedorzecznym”.

15 „Według danej mi łaski Bożej, jako roztropny budowniczy, położyłem fundament, ktoś inny zaś wznosi budynek. Niech każdy jednak baczy na to, jak buduje. Fundamentu bowiem nikt nie może położyć innego, jak ten, który jest położony, a którym jest Jezus Chrystus. I tak jak ktoś na tym fundamencie buduje: ze złota, ze srebra, z drogich kamieni, z drzewa, z trawy lub ze słomy, tak też jawne się stanie dzieło każdego: odsłoni je dzień [Pański]; okaże się bowiem w ogniu, który je wypróbuje, jakie jest. Ten, którego dzieło wzniesione na fundamencie przetrwa, otrzyma zapłatę; ten zaś, którego dzieło spłonie, poniesie szkodę: sam wprawdzie ocaleje, lecz tak jakby przez ogień”.

${ }^{16}$ Por. E. Castellucci, Nella pienezza della gioia pasquale..., dz. cyt., s. 266.

17 Zachętę do pamięci i miłosierdzia wobec zmarłych wrażają słowa: „Miej dar łaskawy wobec każdego, kto żyje, nawet umarłym nie odmawiaj oznak przywiązania” (Syr 7, 33); „Kładź chleby twoje na grobie sprawiedliwych, ale grzesznikom nie dawaj” ( $\mathrm{Tb} 4,17)$. Do odpuszczenia pewnych win po zakończeniu życia nawiązują słowa: „Jeśli ktoś powie słowo przeciw Synowi Człowieczemu, będzie mu odpuszczone, lecz jeśli powie przeciwko Duchowi Świętemu, nie będzie mu odpuszczone, ani w tym wieku, ani w przyszłym” (Mt 12, 32). Na konieczność oczyszczenia się poprzez jakieś zadośćuczynienie wskazują słowa: „Zaprawdę, powiadam ci: nie wyjdziesz stamtąd [z więzienia], aż zwrócisz ostatni grosz” (Mt 5, 26; Łk 12, 59); „Przez to wartość naszej wiary okaże się o wiele cenniejsza od zniszczalnego złota, które przecież próbuje się w ogniu, na sławę, chwałę i cześć przy objawieniu Jezusa Chrystusa [Paruzji]” (1 P 1, 7); „Błogosławieni, którzy płuczą swe szaty, aby władza nad drzewem życia do nich należała i aby bramami wchodzili do Miasta. Na zewnątrz są psy, guślarze, rozpustnicy, zabójcy, bałwochwalcy i każdy, kto kłamstwo kocha i nim żyje” (Ap 22, 14-15).

${ }^{18}$ Cz. St. Bartnik, Dogmatyka katolicka, t. II, (Traktaty VII-XIII), Lublin 2012, s. 857.

19 Por. C. Pozo, Teologia dell'aldilà, Cinisello Balsamo 1986, s. 494-496; J. Ratzinger, Śmierć i życie wieczne, tłum. M. Węcławski, Warszawa 2000, s. 202-207. 
$\mathrm{W}$ odniesieniu do czyśćca „utworzyło się koło hermeneutyczne pomiędzy praktyką liturgiczno-pobożnościową i danymi biblijnymi; koło żyzne, które ponad liczne wypaczenia, odegrało kluczową rolę w ukształtowaniu się doktryny. Praktyka chrześcijańska modlitwy za zmarłych, na wzór tej żydowskiej z 2 Mch, znajduje potwierdzenie w najstarszej liturgii, $w$ tekstach patrystycznych i w świadectwach ikonograficznych i archeologicznych" ${ }^{20}$. Trzeba także pamiętać, że „w pierwszych swych wersjach, a zatem, w tym, co od XII wieku zostanie nazwane czyśćcem (z przejściem od przymiotnika do rzeczownika), zrodziło się z pragnienia rozróżnienia chwały męczenników od tej właściwej dla innych chrześcijan. Modlitwa za zmarłych jest jednak tym trwałym elementem, który wpisze się w tradycję również po epoce męczenników; elementem, który uprzedza i pobudza opracowanie teologiczne i sformułowania urzędowe"21.

\section{Sformułowanie katolickiej nauki o czyśćcu}

Po raz pierwszy sformułowanie katolickiej nauki o czyśćcu dokonało się w średniowieczu i nosi w sobie wyraźne znamię ekumeniczne ${ }^{22}$. Gdy na Soborze Lyońskim II (1274), a następnie na Soborze Florenckim (1439) podjęte zostały próby zjednoczenia Kościoła na Wschodzie i Zachodzie, wówczas również pojawiło się zagadnienie czyśćca obecne w odrębnych tradycjach kościelnych ${ }^{23}$. W Wyznaniu Wiary Michała Paleologa, odczytanym w imieniu cesarza Michała VIII Paleologa na XIV Soborze Powszechnym (II Lyoński - 1274) stwierdza się: „Jeśliby zaś praw-

${ }^{20}$ E. Castellucci, Nella pienezza della gioia pasquale..., dz. cyt., s. 267.

${ }^{21}$ E. Castellucci, Nella pienezza della gioia pasquale..., dz. cyt., s. 268.

${ }^{22}$ Za pierwszą doktrynalną wypowiedź na temat czyśćca uważa się list papieża Innocentego IV z 1254 roku, do kardynała, legata papieskiego na Cyprze. Choć list ten nie miał rangi orzeczenia dogmatycznego, a jedynie był odpowiedzią na różnice pojawiające się w pojmowaniu czyśćca u Greków, to jednak bardzo wyraźnie stwierdza istnienie czyśćca: „Prawda w Ewangelii głosi, że «jeśliby ktoś bluźnił przeciw Duchowi Świętemu, nie będzie mu odpuszczone ani na tym świecie, ani w przyszłym» [Mt 12, 32]. Z tego wnosić można, że pewne winy bywają odpuszczone w obecnym, pewne zaś w przyszłym świecie. Także i Apostoł mówi, «że ogień wypróbuje, jakie są czyny każdego», a «ten, którego czyny zgorzeją, utraci nagrodę; sam wprawdzie będzie zbawiony, ale dopiero po przejściu przez ogień» [1 Kor 3, 13-15]. Mówi się, że Grecy sami prawdziwie i niewątpliwie wierzą i utrzymują, że dusze doznają oczyszczenia po śmierci i mogą doznać pomocy od Kościoła, jeśli wierni - podjąwszy pokutę - umierają nie dopełniwszy jej albo jeśli bez grzechu śmiertelnego, jednak z powszednimi i drobnymi odchodzą z tego świata. Ponieważ mówią, że miejsca tego rodzaju oczyszczenia ich teologowie nie oznaczyli jakąś pewną i określoną nazwą, przeto my zgodnie z tradycją i powagą świętych Ojców nazywając je ‘Czyśćcem’ chcemy, aby i oni w przyszłości tak je nazywali. Tym bowiem przejściowym ogniem oczyszczają się oczywiście grzechy, jednak nie śmiertelne lub ciężkie, które wpierw nie zostały odpuszczone przez pokutę, lecz małe i błahe, które obciążają także po śmierci, nawet jeśli za życia były odpuszczone”. BF VIII, 104 [S. Głowa, I. Bieda (opr.), Breviarium fidei. Wybór doktrynalnych wypowiedzi Kościoła, Poznań 1989].

${ }^{23}$ Por. J. Ratzinger, Śmierć i życie wieczne..., dz. cyt., s. 202-207. 
dziwie pokutujący dokonali życia w miłości jeszcze przed godnym zadośćuczynieniem czynami pokutnymi za popełnione grzechy i zaniedbania, dusze ich, jak to nam brat Jan [Parastron OFM] wyjaśnił, zostaną po śmierci oczyszczone karami czyśćcowymi, czyli ekspijacyjnymi. Do złagodzenia tego rodzaju kar dopomaga wstawiennictwo wiernych żyjących, a mianowicie ofiary Mszy św., modlitwy, jałmużny i inne akty pobożności, które zwykli ofiarować jedni wierni za innych wiernych, zgodnie z postanowieniami Kościoła" ${ }^{24}$. Wyznanie wiary Michała Paleologa zostało włączone do Dekretu dla Greków w 1439 roku na XVII Soborze Powszechnym we Florencji (1438-1445): „Jeśliby prawdziwie pokutujący zakończyli życie w miłości Boga jeszcze przed godnym zadośćuczynieniem czynami pokutnymi za popełnione grzechy i zaniedbania, wówczas dusze ich zostaną po śmierci oczyszczone karami czyśćcowymi. Do złagodzenia tego rodzaju kar dopomaga im wstawiennictwo wiernych żyjących, a mianowicie ofiary Mszy św., modlitwy, jałmużny i inne akty pobożności, które zgodnie z postanowieniami Kościoła jedni wierni zwykli ofiarować za innych wiernych"25. Niewielkie zmiany w tekście Soboru Florenckiego sprowadzają się do pominięcia wzmianki o charakterze kar czyśćcowych (grecki termin catharteriae) oraz o osobie „brata Jana” (Parastron OFM). Jak słusznie zaznacza Tadeusz Dionizy Łukaszuk OSPPE „znamienną cechą przytoczonej definicji jest jej ogromna powściągliwość w posługiwaniu się kategoriami materialno-przestrzennymi w opisie rzeczywistości czyśćca. Nie kładzie się w niej nacisku na to, że istnieje w nim zewnętrzny element kary w postaci ognia. Sama rzecz, o którą soborowi (względnie soborom) chodzi, została opisana przy użyciu słów zaczerpniętych z procesu oczyszczenia (purgari, poenae purgatoriae, catharteriae), tak, że samo łacińskie słowo purgatorium należałoby zgodnie $\mathrm{z}$ intencją tych wypowiedzi tłumaczyć nie tyle jako miejsce, czy nawet stan, lecz jako proces oczyszczania lub samo oczyszczenie. Sposób sformułowania definicji, przyjętej przez sobory unijne, zdaje się być rozmyślnie zastosowany przez jej autorów dla zamanifestowania dystansu oficjalnej nauki Kościoła wobec przesadnie kosmiczno-fizykalnego pojmowania czyśćca przez teologię i literaturę pobożnościową okresu średniowiecza"26.

\footnotetext{
${ }^{24}$ BF VIII, 37.

${ }^{25}$ BF VIII, 112.

${ }^{26}$ T. D. Łukaszuk, Ostateczny los człowieka i świata..., dz. cyt., s. 121.
} 


\section{Kolejne wypowiedzi Magisterium Kościoła}

Sobór Trydencki jako XIX Sobór Powszechny zabierając głos na temat czyśćca przypomniał o jego istnieniu najpierw w Kanonie 30 Dekretu o usprawiedliwieniu (1547): „Jeśli ktoś twierdzi, że po otrzymaniu łaski usprawiedliwienia każdemu grzesznikowi pokutującemu tak jest wina odpuszczona i zgładzona kara wieczna, iż nie zostaje żadna kara doczesna do odpokutowania czy na tym świecie, czy w przyszłym - w czyśćcu - przed wejściem do królestwa niebieskiego - n.b.w."27. Jednym z ostatnich owoców prac Soboru Trydenckiego jest Dekret o czyśćcu z 1563 roku, o charakterze dyscyplinarnym. W pierwszej części tego dekretu Sobór mówi o zdrowej nauce o czyśćcu i o jej podstawach: „Ponieważ Kościół katolicki pouczony przez Ducha Świętego, na podstawie Pisma św. i starożytnej Tradycji Ojców, na świętych Soborach, a ostatnio na tym ekumenicznym [Trydenckim] Soborze podał naukę, że istnieje czyściec, a dusze tam zatrzymane są wspomagane wstawiennictwem wiernych, zwłaszcza zaś miłą [Bogu] Ofiarą Ołtarza - święty Sobór nakazuje biskupom pilnie starać się, ażeby w zdrową naukę o czyśćcu przekazaną przez świętych Ojców i święte Sobory wierni wierzyli, by jej przestrzegano, nauczano i ją wszędzie głoszono"28.

Sobór Watykański II w konstytucji dogmatycznej o Kościele - Lumen gentium stwierdza: „Dopóki tedy Pan nie przyjdzie w majestacie swoim, a wraz z Nim wszyscy aniołowie (por. Mt 25, 31), dopóki po zniszczeniu śmierci wszystko nie zostanie poddane Jemu (por. 1 Kor 15, 26-27), jedni spośród uczniów Jego pielgrzymują na ziemi, inni dokonawszy żywota poddają się oczyszczeniu, jeszcze inni zażywają chwały, widząc «wyraźnie samego Boga troistego i jedynego, jako jest», wszyscy jednak, w różnym stopniu i w rozmaity sposób, złączeni jesteśmy wzajemnie w tej samej miłości Boga i bliźniego i ten sam hymn chwały śpiewamy Bogu naszemu" (KK 49). W dwóch kolejnych numerach Sobór mówi o potrzebie modlitwy za zmarłych w oparciu o praktykę modlitwy istniejącą od początku Kościoła i potwierdzoną przez wcześniejsze sobory: „Uznając w pełni tę wspólnotę całego Mistycznego Ciała Jezusa Chrystusa, Kościół pielgrzymów od zarania religii chrześcijańskiej czcił z wielkim pietyzmem pamięć zmarłych, a "ponieważ święta i zbawienna jest myśl modlić się za umarłych, aby byli od grzechów uwolnieni (2 Mch 12, 46), także modły za nich ofiarował»” (KK 50); „Tę właśnie czcigodną wiarę naszych przodków dotyczącą żywego obcowania z braćmi, którzy są w chwale niebieskiej albo oczyszczają się jeszcze po śmierci, obecny Sobór święty

\footnotetext{
${ }^{27}$ BF VII, 106.

${ }^{28}$ BF VIII, 117 .
} 
Z wielkim pietyzmem przyjmuje i na nowo przedstawia postanowienia w tej mierze świętych Soborów: Nicejskiego II, Florenckiego i Trydenckiego" (KK 51).

Papież Paweł VI w konstytucji apostolskiej Indulgentiarum doctrina z 1 stycznia 1967 roku poświęconej odpustom stwierdza: „Grzechy pociągają za sobą kary nałożone Bożą świętością i sprawiedliwością (z których człowiek uwalnia się) czy to na tym świecie przez cierpienie, dolegliwości i trudy tego życia, a zwłaszcza śmierć, czy to również przez ogień i męki albo kary oczyszczające w przyszłym wieku [...]. Nauka o czyśćcu jasno wykazuje, że obowiązek poniesienia kar, lub usunięcia pozostałości grzechowych może pozostać i rzeczywiście pozostaje, chociaż zostanie odpuszczona już wina: tam bowiem dusze zmarłych, które prawdziwie pokutując, zeszły w miłości Boga, zanim zadośćuczyniły godnymi owocami pokuty za grzechy popełnione i zaniedbania, oczyszczają się po śmierci przez kary czyśćcowe"29.

W wygłoszonym 30 czerwca 1968 roku z racji 1900 rocznicy śmierci św. Pawła uroczystym Wyznaniu wiary, papież Pawła VI przypomina: „Wierzymy w życie wieczne. Wierzymy, że dusze tych zmarłych, którzy umierają w łasce Chrystusowej - czy to mające jeszcze oczyścić się w ogniu czyśćcowym, czy też te, które zaraz po odłączeniu się od ciał, tak jak Dobry Łotr, są przyjmowane przez Jezusa do raju - tworzą lud Boży po śmierci. [...] Wierzymy we wspólnotę wszystkich chrześcijan, a więc tych, którzy pielgrzymują na ziemi, którzy oczyszczają się po zakończeniu życia doczesnego i którzy cieszą się niebieską szczęśliwością, i że wszyscy łączą się w jeden Kościół” (9a).

W 1992 roku Międzynarodowa Komisja Teologiczna wydała dokument pt. Aktualne problemy eschatologii, w którym określa się jasno: „Także Kościół wyznaje, że jakakolwiek zmaza stanowi przeszkodę w wewnętrznym spotkaniu z Bogiem i z Chrystusem. Zasada ta odnosi się nie tylko do zmaz, które przerywają i niszczą przyjaźń z Bogiem - i dlatego, jeśli pozostają w śmierci, uniemożliwiają ostateczne i pełne spotkanie z Bogiem (grzechy ciężkie) - ale również w odniesieniu do zmaz, które zaciemniają tę przyjaźń i muszą być wcześniej oczyszczone, by takie spotkanie było możliwe. Do nich należą tak zwane 'grzechy powszednie', czyli lekkie i pozostałości grzechów, które mogą również pozostać w człowieku usprawiedliwionym po odpuszczeniu winy, wykluczając jednak karę wieczną. Celem sakramentu namaszczenia chorych jest oczyszczenie przed śmiercią pozostałości grzechów. Tylko jeśli stajemy się podobni do Chrystusa, możemy być w komunii z Bogiem (por. Rz 8, 29). Z tego powodu jesteśmy wezwani do oczyszczenia. Kto obmył się, musi jeszcze obmyć proch z nóg (por. J 13, 10). Kościół wierzy, że dla tych, którzy nie uczynili tego w sposób wystarczający na ziemi przez pokutę,

\footnotetext{
${ }^{29}$ Paweł VI, Konstytucja apostolska Indulgentiarum doctrina, Rzym 1967, w: „Posoborowe prawodawstwo kościelne”, Zeszyt 2, Warszawa 1968, nr 2.
} 
istnieje stan oczyszczenia po śmierci, czyli «oczyszczenie, które poprzedza samo oglądanie Boga». Ponieważ takie oczyszczenie dokonuje się po śmierci, a przed ostatecznym zmartwychwstaniem, stan ten należy do pośredniej fazy eschatologicznej; co więcej, jego istnienie potwierdza istnienie eschatologii pośredniej”30.

Katechizm Kościoła Katolickiego podejmuje zagadnienie czyśćca w kilku numerach (m.in. 1030-1032, 1472).

\section{Oczyszczenie czyśćca ze szkodliwych wyobrażeń}

Podobnie jak w przypadku innych prawd wiary sformułowanych jako dogmaty wiary katolickiej (Niepokalane Poczęcie i Wniebowzięcie), także w przypadku czyśćca decydującą rolę odegrał sensus fidelium i szeroko rozumiana pobożność ludowa ${ }^{31}$. Pobożności tej jednak nie zawsze towarzyszyła zdrowa hermeneutyka przez co czyściec stał się obiektem zainteresowania i niezdrowej ciekawości, których przedłużeniem stała się fantazja, w tym także w wymiarze teologicznym i duszpasterskim. W zdecydowanej różnicy od piekła, czyściec umożliwiał kontynuację dotychczasowych więzi na poziomie emocjonalnym. O ile piekło łączono z rzeczywistością niedostępną i zamkniętą, tak w odniesieniu do czyśćca pozostaje możliwość oddziaływania (poprzez modlitwę, ofiarę, jałmużnę, mszę świętą, odpusty, ...). Sama bliskość czyśćca, jak i jego naturalna otwartość w znaczeniu możliwości oddziaływania na stan tam przebywających na przestrzeni historii, zrodziła konieczność oczyszczenia czyśćca z niewłaściwych jego wyobrażeń odpowiadających raczej na ludzką ciekawość niż przyczyniających się do pogłębienia prawdy. Wciąż aktualne pozostają wskazania Soboru Trydenckiego, który mówiąc o czyśćcu bardzo wyraźnie przestrzega w odniesieniu do różnych form przepowiadania: „Zagadnienia dla prostego ludu trudniejsze i subtelniejsze, które nie służą «do zbudowania» [por. 1 Tm 1, 4] i z których najczęściej nie ma żadnego pożytku dla pobożności - z kazań ludowych powinny być wyłączone. Niech nie pozwalają rozszerzać i zajmować się zagadnieniami niepewnymi lub mającymi pozór fałszu. Niech zabronią jako zgorszenia i obrazy dla wiernych tego, co budzi tylko pewną ciekawość lub zabobonność albo trąci brzydką chciwością"”2.

\footnotetext{
${ }^{30}$ Od wiary do teologii. Dokumenty Międzynarodowej Komisji Teologicznej 1969-1996, red. J. Królikowski, s. 327-328.

${ }^{31}$ Por. E. Castellucci, Nella pienezza della gioia pasquale..., dz. cyt., s. 260.

${ }^{32}$ BF VIII, 117 .
} 


\section{Hermeneutyka bardziej krytyczna i proponująca}

W wypracowaniu hermeneutyki pozwalającej jak najlepiej zrozumieć czym jest czyściec element krytyczny pełni niezwykle ważną funkcję. Odnosi się on w pierwszej kolejności do licznych wyobrażeń czyśćca jako miejsca, stanu i czasu. Niewątpliwie już samo słowo „czyściec” (łac. purgatorium, od purgo - czyszczę, oczyszczam) nie jest najbardziej właściwe dla wyrażenia rzeczywistości wyraźnie pozytywnej. Sobór Watykański II wskazał w tym zakresie na większą obecność, tak w teologii, jak i katechezie, takich słów jak oczyszczenie lub dojrzewanie. Wytrwała praca teologów i duszpasterzy winna przyczyniać się do usunięcia idei czyśćca jako pewnego rodzaju czasowego piekła. W tym zestawieniu „kary czyśćca, zatem, muszą być dobrze odróżnione od piekielnych. Każde roszczenie do ustalenia czasu trwania, w istocie, jest bezpodstawne: czyściec jest ponad czasem albo przynajmniej, w innym wymiarze 'czasowym', i jako takiemu nie ma sensu przypisywanie godzin, dni, miesięcy i lat, i ponad wszystko, rościć sobie prawo do poznania efektu chronologicznego wstawiennictwa za zmarłymi. W ten sposób, czyściec zredukowałby się w sposób nieunikniony do jakiejś karykatury: więzienia dusz, które staje się łatwo przedmiotem kpin"33.

Mając na uwadze ujęcie czyśćca postulujące i proponujące bardziej adekwatne jego ujęcie na szczególną uwagę zasługuje kategoria spotkania. W takim znaczeniu „Czyściec jest wymiarem wydarzenia śmierci, a dokładniej spotkania z Chrystusem, które odsłaniając sekrety serc, oczyszcza z pozostałości grzechu i 'wydobywa' zarodki miłości, które zmarły ukazuje"34. Ponadto, co dowartościował zwłaszcza Sobór Watykański II, „nie sposób jest w pełni pojąć rzeczywistość czyśćca jeśli obok kategorii spotkania (oczyszczającego i zadość czyniącego) z miłością trynitarną, nie doda się spotkania z miłością kościelną. Czyściec nie jest rzeczywistością indywidualną, ale wspólnotową: choć to zawsze pojedynczy człowiek ponosi odpowiedzialność za swój stan i związane z nim konsekwencje, to jednak cały Kościół wstawia się za nim"35.

Istnienie czyśćca ukazuje jak bogata jest rzeczywistość Kościoła, który obejmuje pielgrzymujących jeszcze przez ziemię, dostępujących już chwały nieba, a także oczyszczających się w czyśćcu. Kościół jako zjednoczenie wszystkich jego członków w Chrystusie jest Ciałem, którego Głową jest Chrystus. Prawdę o wspólnotowym charakterze Kościoła potwierdza wyznawane w Symbolu Apostolskim

\footnotetext{
${ }^{33}$ E. Castellucci, Nella pienezza della gioia pasquale..., dz. cyt., s. 270.

${ }^{34}$ E. Castellucci, Nella pienezza della gioia pasquale..., dz. cyt., s. 270-271.

${ }^{35}$ E. Castellucci, Nella pienezza della gioia pasquale..., dz. cyt., s. 272.
} 
„obcowanie świętych” (Communio sanctorum) ${ }^{36}$. Solidarność wszystkich członków Kościoła przekracza granice śmierci. Ci wszyscy, którzy stanowią już chwalebne Ciało Chrystusa „przez Niego, z Nim i w Nim nieustannie wstawiają się za nami u Ojca, ofiarując Mu zasługi, które przez jednego Pośrednika między Bogiem a ludźmi, Jezusa Chrystusa (por. 1 Tm 2, 5), zdobyli na ziemi, służąc we wszystkim Panu i w swoim ciele dopełniając niedostatki udręk Chrystusa dla dobra Jego Ciała, którym jest Kościół (por. Kol 1, 24)” (KK 49). Przyzywając wstawiennictwa świętych pielgrzymujący jeszcze przez ziemię zanoszą swe modlitwy w intencji zmarłych ufając, że orędownictwo za nimi przyniesie owoc, którego tu na ziemi nie można w żaden sposób zmierzyćc $c^{37}$.

Istotnym kryterium, które rzuca ważny promień światła na życie poza granicami śmierci, jest miłość. Patrząc od strony miłości „zmarły, w istocie, kontynuuje swe życie: i nie tylko dlatego, że wchodzi w życie niebiańskie, ale również dlatego, że relacje miłości jakie on nawiązał w swoim życiu ziemskim kontynuują swe działanie w świecie; myślimy o dobru wykonanym przez niezliczonych przyjaciół Boga, które przedłuża się ponad ich istnienie ziemskie i, raczej, okazuje się w całej pełni czasami właśnie dopiero po ich śmierci; myślimy o miłości ojca lub matki, która rodzi owoce $\mathrm{w}$ dzieciach, pomimo ich nieobecności na ziemi; myślimy również o przyjacielu, który zakończywszy swoje istnienie na ziemi, kontynuuje w rzeczywistości określanie zachowań, sentymentów i myśli u osób, które nie mogą pogodzić się z jego odejściem. To wszystko oznacza, że życie człowieka, który kocha przekracza tę samą osobę, wciąga innych i na nich wpływa, kontynuuje dając owoce także po śmierci: i to dokonuje się w określonej mierze miłości, którą ta osoba kochała" ${ }^{38}$. Osoba, która w swym życiu potrafiła kochać, w przeciwieństwie do osoby, która myślała tylko o sobie, żyje dalej. Wstawiennictwo żyjących jeszcze na ziemi za tymi, którzy przekroczyli już granicę śmierci wyrasta na śladach miłości okazanych przez tychże zmarłych w czasie ich ziemskiego

\footnotetext{
${ }^{36}$ Por. G. Greshake, Il Dio unitrino. Teologia trinitaria, Brescia 200o, s. 495; A. A. Napiórkowski, Misterium communionis. Eklezjalny paradygmat dziejów zbawienia, Kraków 2006, s. 266-273.

37 „Stąd też, jak wynika z dogmatu Świętych Obcowania, czyli Komunii świętych (KKK 962), dusze w czyśćcu mogą się modlić za siebie, w intencji innych dusz czyśćcowych i w intencji żyjących, a żyjący mogą się modlić do dusz i za dusze, choć dokonuje się to przez pośrednictwo i wstawiennictwo Chrystusa i Matki Jego u Boga. Z kolei i dusze świętych w stanie nieba wstawiają się za duszami w czyśćcu. Nie można przy tym wykluczyć, że święty kanonizowany, do którego się możemy modlić in Christo, pozostaje jeszcze w stanie czyśćcowym. Kanonizacja daje pewność, że dana dusza jest zbawiona, ale nie daje pewności, że jest już w niebie, a dusze czyśćcowe znajdują się już na drodze do nieba. Przejście między stanem czyśćca a stanem niebiańskim nie jest drogą nad przepaścią. Droga ta to bardziej ciągłość niż nieciągłość”. Cz. St. Bartnik, Dogmatyka katolicka..., dz. cyt., s. 860.

${ }^{38}$ E. Castellucci, Nella pienezza della gioia pasquale..., dz. cyt., s. 274.
} 
życia. Modlitwa zaś za zmarłych nieznanych z imienia znajduje swoje uzasadnienie w powszechnym wymiarze miłości, którą żyjący winni okazywać wszystkim.

W wymiarze eklezjalnym czyśćca zawiera się jeszcze inny ważny element odpowiedniej hermeneutyki teologicznej jakim jest ciągłość pomiędzy istnieniem ziemskim i obejmującym czyściec ${ }^{39}$. Jak podkreśla kard. Christoph Schönborn: „Czyściec nie może zaczynać się tylko po śmierci. Próby, przyjęte w wierze, są już czyśćcem na ziemi. Ciężka choroba może być drogą oczyszczenia" ${ }^{30}$. W perspektywie podstawowej ciągłości „rozumienie życia ziemskiego przy użyciu słowa 'czyściec' pomaga zrozumieć lepiej podstawowy element eschatologii chrześcijańskiej, który powtarza się ciągle: wymiar niebiański nie rozumie się jako nagrodę lub karę, która przyjdzie nagle i niespodziewanie pewnego dnia, i która nie będzie miała żadnego związku z aktualnym życiem, ale - wręcz przeciwnie - jako dopełnienie decyzji i działań, które w życiu ziemskim, dzień po dniu, są realizowane. Życie wieczne zaczyna się, jest potwierdzone i realizowane w życiu ziemskim, które pozostawia w nim niezmywalny ślad" ${ }^{41}$. W bliskim związku z czyśćcem już tu na ziemi pozostają takie rzeczywistości służące oczyszczeniu jak sakrament pojednania i praktyka odpustów ${ }^{42}$.

\section{Zakończenie}

Starając się odpowiedzieć na pytanie o sens i znaczenie dogmatu o czyśćcu dla człowieka współczesnego wchodzimy w obręb hermeneutyki, która jako sztuka interpretacji pomaga teologii prowadzić konstruktywny dialog pomiędzy teraźniejszością i przeszłością w przekazywaniu niezmiennej prawdy. Katolicka nauka o czyśćcu wyrosła z praktyki modlitw za zmarłych i jest oparta na Piśmie Świętym, starożytnej Tradycji i na soborach. Wypracowanie kompromisowej formuły nauki o czyśćcu pomiędzy Wschodem a Zachodem dokonało się na dwu unijnych soborach średniowiecza: Lyońskim II (1274) i Florenckim (1439). Odczytanie niejako na nowo i w nowych okolicznościach dotychczas ustalonych sformułowań nastąpiło na Soborze Trydenckim (Dekret o czyśćcu - 1563), a po kolejnych prawie 400 latach, przypomniano je na Soborze Watykańskim II.

Wraz z mającym miejsce w XX wieku „rozbudzeniem” eschatologii w obrębie teologii katolickiej i odkryciem niezwykłego bogactwa nadziei chrześcijańskiej,

\footnotetext{
${ }^{39}$ Por. E. Castellucci, Nella pienezza della gioia pasquale..., dz. cyt., s. 275.

${ }^{40} \mathrm{Ch}$. Schönborn, Al centro della nostra fede. Il „Credo” nel Catechismo della Chiesa cattolica, Milano 1997, s. 120. Por. B. Mondin, Gli abitanti del cielo. Trattato di ecclesiologia celeste e di escatologia, Bologna 1994, S. 141.

${ }^{41}$ E. Castellucci, Nella pienezza della gioia pasquale..., dz. cyt., s. 276.

${ }^{42}$ Por. E. Castellucci, Nella pienezza della gioia pasquale..., dz. cyt., s. 276.
} 
w pierwszej kolejności również w odniesieniu do katolickiej nauki o czyśćcu bardziej oczywistym stał się postulat odejścia od upowszechnionych zwłaszcza poprzez przepowiadanie przestrzenno-czasowych wyobrażeń czyśćca, na rzecz ukazania jego istoty w kategoriach spotkania z Chrystusem. To zdecydowane zwrócenie się ku Chrystusowi w rzeczywistości czyśćca oznacza taką jego hermeneutykę, która bardziej jeszcze ukazuje go w perspektywie miłości, ciągłości i przekraczającej granice śmierci komunii. Dzięki dowartościowaniu przez Sobór Watykański II niezwykłego bogactwa prawdy o świętych obcowaniu, Lumen Christi opromieniło także mroki czyśćca. Prawda o tym, że człowiek wierzący nigdy nie jest sam (por. encyklika Lumen fidei, 39), nie traci nic ze swej niezwykłości także w odniesieniu do tych, którzy po przekroczeniu progu śmierci nie stali się jeszcze uczestnikami bezpośredniego oglądu Boga i uczestniczą w koniecznym oczyszczeniu. Prawda o czyśćcu pokazuje wyraźnie, że śmierć nie jest silniejsza od miłości i wspólnoty dóbr duchowych, które jednoczą w jednym Kościele pielgrzymujących jeszcze na ziemi, poddających się oczyszczeniu i zażywających chwały nieba.

\section{Proponowana literatura}

Arminjon Ch., Koniec świata doczesnego i tajemnice życia przyszłego: Konferencje, tłum.

B. Dyrda, Poznań 2011.

Bartnik Cz. St., Dogmatyka katolicka, t. II (Traktaty VII-XIII), Lublin 2012.

Benedykt XVI, Posynodalna adhortacja apostolska Verbum Domini.

Bokwa I., Gott ist Fülle, Sandomierz 2004.

Buxakowski J., Wieczność i człowiek: Eschatologia, Pelplin 2009.

Camillò R., Cose dell'Altro mondo. I Novissimi e dintorni, Verona 2011.

Castellucci E., Nella pienezza della gioia pasquale. La centralità dell'ermeneutica nell'escatologia cristiana, Bologna 1998.

De Rosa G., Il purgatorio: Fede cattolica e „immaginario” popolare, „Civiltà Cattolica” 151/2 (2000), s. 352-365.

Greshake G., Il Dio unitrino. Teologia trinitaria, Brescia 2000.

Jan Paweł II, Encyklika Fides et ratio.

Jankowski A., Eschatologia biblijna Nowego Testamentu, Kraków 1987.

Kijas Z., Czyściec oczekiwaniem nieba, Częstochowa 2003.

Łukaszuk T. D., Ostateczny los człowieka i świata w świetle wiary katolickiej, Kraków 2006. Napiórkowski A. A., Misterium communionis. Eklezjalny paradygmat dziejów zbawienia, Kraków 2006. 
Niebo - Piekło - Czyściec: Spojrzenie Kościoła, red. K. Czapla, P. Góralczyk, W. Chrostowski, M. Starowieyski, Cz. Parzyszek, J. Salij, A. Zwoliński, Ząbki 2010.

Nowak M., Wieczność zaczyna się tu, Warszawa 1999.

O’Donnell J., Wprowadzenie do teologii dogmatycznej, tłum. J. D. Szczurek, Kraków 1997.

Pozo C., Teologia dell'aldilà, Cinisello Balsamo 1986.

Pylak B., Życie zmienia się, ale nie kończy, Lublin 2000.

Rudoni A., Introduzione all'escatologia, Torino 1988.

Schamoni W., Die Seele und ihr Weiterleben nach dem Tode. Abdruck von 63 Texten aus 11 Jahrgängen der Beilage "Theologisches“ in der Offerten-Zeitung für die katholische Geistlichkeit, Abensberg 1981.

Schönborn Ch., Al centro della nostra fede. Il „Credo” nel Catechismo della Chiesa cattolica, Milano 1997.

Scuola di Teologia del Seminario di Bergamo (a cura di), Teologia dal Vaticano II. Analisi storiche e rilievi ermeneutici, Cinisello Balsamo 2012.

Skwierczyński A., Miłość oczyszczająca. Współczesna interpretacja katolickiej nauki o czyśćcu, Warszawa 1992.

Zwoliński A., Kontakt ze zmarłymi i wędrówka dusz czyśćcowych, Kraków 2013. 